\title{
Mężczyzna i kobieta w ujęciu katechez środowych Jana Pawła II
}

\section{Wprowadzenie}

Można zaryzykować twierdzenie, że żaden papież w swym nauczaniu nie poświęcił problematyce małżeństwa i rodziny tyle miejsca, co św. Jan Paweł II. Szczególnym tego wyrazem są tzw. „katechezy środowe” - cykl Mężczyzna i niewiasta stworzył ich... Refleksja papieska ściśle łączy ze sobą mężczyznę i kobietę, męża i żonę, ojca i matkę - zgodnie z powołaniem, jakie Bóg postawił przed ludźmi, stwarzając ich w postaci dwóch odmiennych płci. Niniejszy artykuł stanowi próbę wydobycia z tego bogatego i ważnego nauczania specyficznych elementów dotyczących mężczyzny, męża i ojca. Wprowadzeniem do tej analizy mogą być słowa, które Jan Paweł II wypowiedział o swoim własnym ojcu: „Mój ojciec był wspaniały i prawie wszystkie moje wspomnienia z dzieciństwa i młodości odnoszą się do niego. Gwałtowność ciosów, które go ugodziły, otworzyły w nim niezmierzone głębie duchowe, jego zmartwienie stawało się modlitwą. Prosty fakt, że 
widziałem go na klęczkach, miał decydujący wpływ na moje młode lata. Był tak bardzo wymagający wobec siebie, że nie miał już potrzeby okazywania się wymagającym wobec syna: jego przykład wystarczał, by nauczyć dyscypliny i poczucia obowiązku"1.

Środowe przemówienia Jana Pawła II zostały wygłoszone podczas audiencji ogólnych w okresach: 5 października 1979-2 kwietnia 1980; 11 listopada 1981-9 lutego 1983; 23 maja-28 listopada 1984. Zawartą w nich tematykę wyraźnie określa tytuł i podtytuł dany katechezom: Mężczyzna i niewiasta stworzył ich. Odkupienie ciała a sakramentalność małżeństwa ${ }^{2}$.

Nauczanie papieskie dzieli się na dwie części. W części pierwszej Jan Paweł II analizuje słowa Chrystusa: najpierw te, które w trakcie dyskusji z faryzeuszami na temat jedności i nierozerwalności małżeństwa odwołują się do „początku” (por. Mt 19,8; Mk 10,6-9.), następnie fragmenty Ewangelii mówiące o „pożądaniu” jako „cudzołożeniu w sercu” z Chrystusowego Kazania na górze (por. Mt 5,28) i wreszcie cytowane przez synoptyków słowa o zmartwychwstaniu ciał w „przyszłym świecie” (por. Mt 22,30; Mk 12,25; Łk 20,35).

Drugą część swoich katechez środowych o małżeństwie Jan Paweł II poświęcił niektórym aspektom sakramentu małżeństwa. Analizuje w nich tekst z Listu do Efezjan (Ef 5,21-33), w którym św. Paweł nawiązuje do biblijnego „początku”, przytaczając słowa Księgi Rodzaju: „Przeto opuści człowiek ojca i matkę, a połączy się z żoną swoją, i będą dwoje jednym ciałem”( $\mathrm{Rdz}$ 2,24). Katechezy środowe Jana Pawła II stanowią pierwszą próbę całościowej syntezy teologii ciała w nauczaniu Magisterium Kościoła. Na tym tle papież ukazuje ścisły związek między odkupieniem ciała a sakramentalnością małżeństwa. Siła jego argumentacji teologicznej opiera się na słowach Objawienia: „stają się dwoje jednym ciałem” (Rdz 2,24). W swej refleksji nad sakramentem małżeństwa papież wskazuje na dwa podstawowe wymiary

1 Cyt. za A. Frossard, N’ayez pas peur, Paris 1982, tłumaczenie własne. Warto dodać, że na mocy decyzji księdza arcybiskupa Marka Jędraszewskiego rozpoczął się w Krakowie proces przygotowawczy do beatyfikacji rodziców św. Jana Pawła II: Karola i Emilii.

2 Autoryzowany i pełny tekst polski, pod redakcją księży S. Dziwisza, J. Kowalczyka, T. Rakoczego, został wydany przez Libreria Editrice Vaticana: Jan Paweł II, Mężczyzną i niewiasta stworzył ich. Odkupienie ciała a sakramentalność małżeństwa, Watykan 1986. W niniejszej pracy opieramy się na tym tekście i stosujemy skrót: Mężczyzną i niewiastą stworzył ich oraz numer strony. Termin „katechezy środowe”, bez dodatkowych określeń, wskazuje że chodzi nam o ten właśnie dokument. Komentowane przez papieża cytaty z Pisma Świętego pochodzą także z tego tekstu. 
każdego sakramentu: wymiar przymierza i łaski oraz wymiar znaku. „Poprzez oba te wymiary sięgamy stale do rozważań teologii ciała, związanych z kluczowymi słowami Chrystusa"3.

W końcowej części katechez na temat małżeństwa Jan Paweł II przedstawia swoją interpretację encykliki Pawła VI Humanae vitae. „Nauka zawarta $\mathrm{w}$ tym dokumencie współczesnego nauczania Kościoła pozostaje w organicznym związku zarówno $\mathrm{z}$ sakramentalnością małżeństwa, jak i z całą biblijną problematyką teologii ciała, skoncentrowaną wokół «kluczowych»

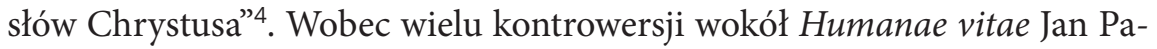
weł II nie waha się określić swoich katechez jako „rozbudowanego komentarza” do nauki zawartej właśnie w tej encyklice ${ }^{5}$.

\section{Biblijny „początek”}

Punktem wyjścia dla nauczania Jana Pawła II jest fragment Ewangelii przedstawiający dyskusję Chrystusa z faryzeuszami na temat małżeństwa ${ }^{6}$. Według papieża szczególne znaczenie ma fakt, że w tej rozmowie Chrystus dwukrotnie odwołuje się do „początku”, wprowadzonego przez Stwórcę człowieka - mężczyzny i kobiety. Skłoniło to ojca świętego Jana Pawła II do podjęcia szczegółowej analizy tego „początku”, „który jest pierwszym dziedzictwem każdego na świecie człowieka, mężczyzny i kobiety: pierwszym źródłem tożsamości człowieka w słowie objawienia, pierwszym źródłem jego powołania jako osoby stworzonej na obraz Boga samego"' . Odpowiedź Chrystusa przypomniała podstawowe prawdy o człowieku jako mężczyźnie i kobiecie, w świetle tajemnicy stworzenia i odkupienia. Z niej czerpiemy ową „,integralną wizję człowieka”, do której odwołał się Paweł VI w encyklice Humanae vitae $e^{8}$ a którą mężczyzna i kobieta muszą sobie uświadomić, by ją realizować w ramach powołania małżeńskiego. Małżeństwo bowiem jest specyficzną drogą świętości i zbawienia.

\footnotetext{
Jan Paweł II, Mężczyzna i niewiasta stworzyt ich, dz. cyt., s. 6. Jan Paweł II, Mężczyzna i niewiasta stworzył ich, dz. cyt., s. 6. Jan Paweł II, Mężczyzna i niewiasta stworzyt ich, dz. cyt., s. 6. Mt 19,3-8; Mk 10,2-9. Jan Paweł II, Mężczyzna i niewiastą stworzył ich, dz. cyt., s. 93. Paweł VI, Encyklika Humanae vitae, 7.
} 


\subsection{Pierwotna jedność}

Katechezy środowe Jana Pawła II dają syntezę nie tylko teologii ciała czy płciowości ludzkiej, lecz równocześnie ukazują teologię wzajemnych relacji między mężczyzną a kobietą w małżeństwie. Sięgając, stosownie do słów Chrystusa, do biblijnego „początku”, papież analizuje trzy istotne elementy, ściśle ze sobą powiązane: pierwotna samotność, pierwotna jedność, pierwotna nagość. Każdy z nich odnosi się także do mężczyzny i dlatego może być przedmiotem obszernych rozważań. Ze względu na temat artykułu uwypuklamy zagadnienie pierwotnej jedności.

Chrystus w rozmowie z faryzeuszami odwołuje się do słów Księgi Rodzaju: „opuszcza człowiek ojca swego i matkę swoją i łączy się ze swą żoną tak ściśle, że stają się jednym ciałem"'. Tak więc pierwotna jedność sięga swymi korzeniami do faktu stworzenia człowieka jako mężczyzny i kobiety. „Człowiek” („Adam”) zapada w „głęboki sen”, aby zbudzić się z niego "mężczyzną i niewiastą". Dzięki stwórczemu działaniu Boga początkowo „samotny” człowiek staje się człowiekiem w jedności dwojga osób: mężczyzny i kobiety.

Jan Paweł II określa wymiary tej jedności. Obejmuje ona całą istotę obojga - mężczyzny i kobiety - nie tylko ich ciało, strukturę somatyczną, ale równocześnie całe ich człowieczeństwo. $\mathrm{W}$ opisie biblijnym dochodzi do głosu radość mężczyzny na widok drugiego człowieka: stworzonej przez Boga kobiety ${ }^{10}$. „W ten sposób Stworzenie człowieka jest to stworzenie owej jedności dwojga, przy czym jedność oznacza przede wszystkim tożsamość natury - człowieczeństwa, dwoistość natomiast oznacza wszystko to, czym na gruncie tożsamości człowieczeństwa okazuje się męskość i kobiecość stworzonego człowieka" ${ }^{11}$. Papież podkreśla, że człowiek został stworzony jako szczególna wartość wobec Boga, ale równocześnie jako szczególna wartość dla drugiego człowieka: kobieta dla mężczyzny, mężczyzna dla kobiety. Wyraz radości mężczyzny na widok „wziętej z niego" niewiasty ${ }^{12}$ może być uznany za prototyp biblijnej Pieśni nad Pieśniami ${ }^{13}$.

\footnotetext{
$9 \quad \operatorname{Rdz} 2,24$.

10 Por. Rdz 2,23.

11 Jan Paweł II, Mężczyzną i niewiastą stworzył ich, dz. cyt., s. 37.

$12 \operatorname{Rdz} 2,23$.

13 Jan Paweł II, Mężczyzną i niewiastą stworzył ich, dz. cyt., s. 38.
} 
W katechezach środowych znajduje także swój wyraz droga Janowi Pawłowi II idea communio personarum (komunii osób), określająca najpełniej związek mężczyzny i kobiety w małżeństwie. Papież podkreśla, że termin „wspólnota” jest niewystarczający. Pojęcie „komunia” jest pełniejsze i bardziej adekwatne, „(...) mówi więcej i mówi ściśle: oznacza właśnie ową "pomoc» płynącą poniekąd z samego faktu zaistnienia osoby «obok» osoby $(. .$.$) «dla»$ osoby” 14 . Słowo „komunia” nawiązuje także do biblijnego terminu „pomoc”, zawartego w znamiennym fragmencie Księgi Rodzaju: „Nie jest dobrze, żeby człowiek (mężczyzna) był sam; uczynię mu zatem odpowiednią dla niego pomoc"15. Rozumiana jest ona także jako wzajemność w bytowaniu, której nie była w stanie dać pierwszemu człowiekowi żadna inna istota żyjąca.

Jan Paweł II opiera się na obu opisach stworzenia człowieka: jahwistycznym i kapłańskim. Wyprowadza z nich wniosek, że „obrazem i podobieństwem Boga stał się człowiek nie tylko przez samo człowieczeństwo, ale także poprzez komunię osób, którą stanowią od początku mężczyzna i niewiasta"16. Tak więc człowiek odzwierciedla Boga nie tyle w akcie samotności, ile w akcie komunii między mężczyzną a kobietą. Papież nie waha się w tym miejscu, wbrew zastrzeżeniom ze strony niektórych biblistów, sięgnąć wprost do analogii trynitarnej. Mężczyzna i kobieta w akcie wzajemnej komunii są obrazem Boskiej komunii Osób w Trójcy Świętej. Opis jahwistyczny stworzenia człowieka pomaga w tym wypadku w trynitarnym rozumieniu „obrazu Bożego” zawartego w opisie kapłańskim ${ }^{17}$.

Analizując słowa pierwszego człowieka - mężczyzny - wypowiedziane na widok pierwszej kobiety: „kość z moich kości i ciało z mojego ciała”18, Jan Paweł II snuje refleksję na temat teologii ciała. Nauka ta wypływa z faktu stworzenia człowieka (jako mężczyzny i kobiety) na obraz Boży. Przybiera ona charakter teologii płci, a raczej teologii męskości i kobiecości, która czerpie swój początek z Księgi Rodzaju. Ojciec święty mówi w tym miejscu o jedności mężczyzny i kobiety, realizującej się poprzez ciało: „łączą się ze sobą tak ściśle, że stają się jednym ciałem"19. Jedność ta ma dwa główne wymiary: etyczny i teologiczny. Pierwszy ujmuje wypowiedź Chrystusa

\footnotetext{
14 Jan Paweł II, Mężczyzną i niewiastą stworzył ich, dz. cyt., s. 39.

$15 \operatorname{Rdz} 2,18$.

16 Jan Paweł II, Mężczyzną i niewiasta stworzył ich, dz. cyt., s. 39.

17 Jan Paweł II, Mężczyzną i niewiasta stworzył ich, dz. cyt., s. 40.

$18 \mathrm{Rdz} 2,23$.

$19 \operatorname{Rdz} 2,24$.
} 
zwróconą do faryzeuszów ${ }^{20}$. Teologiczny wymiar sakramentalny odnajdujemy w Liście św. Pawła do Efezjan ${ }^{21}$, który nawiązuje do tradycji proroków, zwłaszcza Ozeasza, Izajasza i Ezechiela. „Owa jedność poprzez ciało wskazuje od początku nie tylko na ciało, ale na "wcieloną» komunię osób - i tę komunię: «communio personarum» od początku postuluje (...). Kobiecość niejako odnajduje siebie w obliczu męskości, podczas gdy męskość potwierdza się przez kobiecość (...). Obecność pierwiastka kobiecego obok męskiego, i wespół z nim, posiada znaczenie wzbogacające dla człowieka w całej perspektywie jego dziejów - również i dziejów zbawienia”22.

\subsection{Zjednoczenie małżeńskie}

Jan Paweł II stwierdza wyraźnie, że jedność, o której mówi Rdz 2,24, wyraża się i urzeczywistnia w zjednoczeniu małżeńskim. „Sformułowanie biblijne, nadzwyczaj zwięzłe i proste, wskazuje na płeć, na kobiecość i męskość, jako na właściwość człowieka - mężczyzny i kobiety - która pozwala im «stając się jednym ciałem», poddać zarazem całe swoje człowieczeństwo błogosławieństwu płodności”23. Zjednoczenie małżeńskie jest więc udziałem w tajemnicy stworzenia. Gdy mężczyzna i kobieta stają się poprzez nie „jednym ciałem”, czynią widoczną tym samym więź ustanowioną przez Stwórcę; „odkrywają swoje człowieczeństwo zarówno w pierwotnej jedności, jak też w tajemniczo atrakcyjnej dwoistości”24.

Aby ta niezwykła jedność między mężczyzną a kobietą mogła zaistnieć, konieczny staje się wolny wybór z ich strony. Opierając się na $\operatorname{Rdz} 2,24$, papież podkreśla, że do ojca i matki człowiek przynależy z natury, z racji aktu zrodzenia. Ze współmałżonkiem natomiast „łączy się” z wyboru. Jezus Chrystus powołuje się na ten właśnie tekst, uświadamiając swoim słuchaczom jego moc obowiązującą: „Ukonstytuowani na obraz Boga także przez to, że stanowią autentyczną wspólnotę (komunię) osób, pierwsi: mężczyzna i niewiasta, mają stanowić początek i wzór takich samych wspólnot komunii dla wszystkich mężczyzn i kobiet, którzy kiedykolwiek będą się

\footnotetext{
20 Mt 19,3-9; Mk 10,2-12.

21 Ef 5,29-32.

22 Jan Paweł II, Mężczyzną i niewiastą stworzył ich, dz. cyt., s. 41-42.

23 Jan Paweł II, Mężczyzna i niewiasta stworzył ich, dz. cyt., s. 42-43.

24 Jan Paweł II, Mężczyzną i niewiastą stworzył ich, dz. cyt., s. 43.
} 
łączyć z sobą «tak ściśle, że staną się jednym ciałem» (...). Dokonuje się to jednakże przez wzajemny wybór. Wybór stanowi o małżeńskim «przymierzu osób», które dopiero w oparciu o ten wybór «stają się jednym ciałem»"25. W tej jedności małżonków ciało ma więc do spełnienia zasadniczą rolę. Dzięki swojej męskości i kobiecości, w ich wzajemnym zjednoczeniu, ukazuje życiodajną głębię i moc tajemnicy stworzenia. Takie spojrzenie na zjednoczenie małżeńskie, na funkcję ciała w tym zjednoczeniu, wyznacza jasne i konkretne prawa, obowiązki i zadania zarówno przed mężem, jak i przed żoną. Można je określić mianem powołania. Dlatego „ci, którzy szukają w małżeństwie spełnienia swego ludzkiego i chrześcijańskiego powołania, przede wszystkim są wezwani, aby uczynić treścią swego życia i postępowania ową «teologię ciała», której «początek» znajdujemy w pierwszych rozdziałach Księgi Rodzaju”26.

\subsection{Wymiar daru w komunii małżeńskiej}

W katechezach środowych Jan Paweł II przeprowadza refleksję, którą sam określa jako „hermeneutyka daru”. Relacje między mężczyzną a kobietą $\mathrm{w}$ małżeństwie ujmuje $\mathrm{w}$ perspektywie wzajemnego daru z siebie. Jest on elementem miłości małżeńskiej, w specyficzny sposób wyraża się poprzez ciało. „W ciele ludzkim została zawarta «od początku» właściwość oblubieńcza, czyli zdolność wyrażania miłości, tej właśnie miłości, w której człowiek - osoba staje się darem i spełnia sam sens swego istnienia i bytowania poprzez ten dar"27. Ta wzajemna ofiara między mężem a żoną jest znakiem komunii osób, którą tworzą. Ciało wyrażające element męskości jest darem dla kobiety; ciało wyrażające element kobiecości - darem dla mężczyzny. Jezus Chrystus, odwołując się do „początku”, chce powiedzieć człowiekowi, że droga, którą on prowadzi mężczyznę i kobietę w sakramencie małżeństwa, jest drogą „odkupienia ciała” i musi ona polegać na odzyskiwaniu tej godności, w jakiej realizuje się prawdziwy sens ciała ludzkiego - osobowy i komunijny zarazem ${ }^{28}$.

\footnotetext{
25 Jan Paweł II, Mężczyzną i niewiasta stworzył ich, dz. cyt., s. 44.

26 Jan Paweł II, Mężczyzną i niewiastą stworzył ich, dz. cyt., s. 96.

27 Jan Paweł II, Mężczyzna i niewiasta stworzył ich, dz. cyt., s. 61.

28 Jan Paweł II, Mężczyzną i niewiastą stworzył ich, dz. cyt., s. 97.
} 
Jan Paweł II wymienia i omawia istotne cechy tego wzajemnego daru, który komunikują sobie małżonkowie. Jest to przede wszystkim dar osobowy, a więc świadomy i dobrowolny: małżeństwo jest przecież komunią dwóch różniących się, ale równocześnie uzupełniających się osób. Musi być on więc darem wolnym, w przeciwnym bowiem wypadku przekreślałby oblubieńcze znaczenie ciała, a nawet sens jedności i miłości małżeńskiej. Wobec częstego fałszowania i nadużywania pojęcia wolności papież definiuje to je odniesieniu do małżeństwa: „Wolność rozumiemy w tym miejscu przede wszystkim jako posiadanie siebie samego (samoposiadanie). W tej postaci bowiem jest ona nieodzowna, ażeby człowiek mógł «siebie dawać», ażeby mógł stawać się darem, ażeby (nawiązując do słów Soboru) mógł «odnajdywać siebie przez bezinteresowny dar z siebie»"29. Jan Paweł II dokonuje wnikliwej analizy tego fragmentu konstytucji Gaudium et spes, opierając na niej swoje wnioski. Jest rzeczą znamienną, że ten właśnie papież często odwołuje się do nauczania II Soboru Watykańskiego, także w kwestiach dotyczących małżeństwa i rodziny. Dar ze siebie powinien być także darem bezinteresownym. Przypomina o tym zarówno II Sobór Watykański, we wspomnianym powyżej tekście, jak i Jan Paweł II w swojej refleksji. Bezinteresowność wyklucza wyrachowanie, „zimną kalkulację”, tak często dochodzące do głosu w małżeństwach epoki minionej oraz czasów współczesnych. Ofiarując siebie, ofiarując swoje ciało jako dar ukochanej osobie, nie można tego czynić w imię jakiegoś interesu. Wolny i bezinteresowny dar ze siebie samego nie może być uszczupleniem osoby, lecz jej afirmacją, która obejmując całość osoby, ogarnia tym samym ludzkie ciało. W świecie, który zarzuca Janowi Pawłowi II konserwatyzm w nauczaniu na temat małżeństwa i rodziny, a zwłaszcza w dziedzinie etyki seksualnej, warto zastanowić się nad tym w pewnym sensie rewolucyjnym stwierdzeniem: „ "Afirmacja osoby» to nic innego jak podjęcie daru, które poprzez wzajemność stwarza komunię osób: konstytuuje ją od wewnątrz, a równocześnie ogarnia nią i obejmuje całą «zewnętrzność» człowieka, to co stanowi jego nagość, czystą i prostą nagość ciała w jego męskości i kobiecości”30.

Wolny, bezinteresowny dar z siebie odwołuje się zawsze do istoty miłości ludzkiej, miłości między kobietą a mężczyzną, między mężem a żoną.

29 Sobór Watykański II, Konstytucja Gaudium et spes, 24; Jan Paweł II, Mężczyzną i niewiastą stworzył ich, dz. cyt., s. 62.

30 Jan Paweł II, Mężczyzną i niewiastą stworzył ich, dz. cyt., s. 64. 
Rzeczywistość daru i obdarowania mieści się w tajemnicy promieniowania miłości. Tak pojęta miłość absorbuje uczucie wstydu, jak to miało miejsce „na początku”, do którego odwołuje się Chrystus.

\section{4. „Poznanie” i rodzenie}

Grzech pierworodny zranił głęboko człowieka, naruszył jego wewnętrzną harmonię. Ugodził także w jedność, którą z woli Stwórcy stanowiła pierwsza para ludzka: „Grzech i śmierć weszły w dzieje człowieka niejako przez samo serce tej jedności, jaką «od początku» stanowili mężczyzna i kobieta, stworzeni i wezwani do tego, aby «stawać się jednym ciałem»"31. Rozważania nad biblijnym początkiem mężczyzny i kobiety Jan Paweł II kończy obszerną refleksją nad słowami zaczerpniętymi z czwartego rozdziału Księgi Rodzaju: „Mężczyzna zbliżył się do swej żony Ewy, a ona poczęła i urodziła Kaina, i rzekła: «Urodziłam mężczyznę z pomocą Jahwe». A potem urodziła jeszcze Abla, jego brata"32. Papież zwraca uwagę na fakt, że dawne przekłady używały wyrażenia: „mężczyzna poznał swą żonę”, co bardziej odpowiadało określeniu semickiemu z Biblii - jada. „Poznanie” polega więc na tym, że "mężczyzna i jego żona łączą się ze sobą tak ściśle, że stają się jednym ciałem”33. Tekst biblijny wydaje się uzależniać to „poznanie” od decyzji mężczyzny, dlatego komentarz papieski akcentuje równość mężczyzny i kobiety także w tej dziedzinie: „Rdz 4,1-2 mówi tylko o poznaniu kobiety przez mężczyznę, jakby wskazując na jego przede wszystkim aktywność. Można jednakże mówić o wzajemności tego "poznania», w którym mężczyzna i kobieta uczestniczą przez swoje ciało i płeć"34. Słowo „poznanie” wskazuje na sens pożycia małżeńskiego, na wartość ciała i płci ludzkiej i odnosi te treści do koncepcji „daru”. Jan Paweł II akcentuje ścisły związek między tymi pojęciami: „W owym małżeńskim "poznaniu» kobieta jest «dana» mężczyźnie, a on jej, ponieważ ciało i płeć wchodzi bezpośrednio w samą strukturę i treść tego «poznania»"35.

\footnotetext{
$31 \quad \operatorname{Rdz} 2,24$.

$32 \operatorname{Rdz} 4,1-2$.

33 Por. Rdz 2,24. Ten bogaty w treść termin biblijny doczekał się obfitej literatury. W cytowanym tekście odnosi się on do sfery życia seksualnego i oznacza stosunek małżeński.

34 Jan Paweł II, Mężczyzną i niewiasta stworzył ich, dz. cyt., s. 81.

35 Jan Paweł II, Mężczyzną i niewiastą stworzył ich, dz. cyt., s. 82.
} 


\subsection{Ojcostwo i macierzyństwo}

Jan Paweł II naucza z całą stanowczością, że najgłębszym sensem biblijnego „poznania” są ojcostwo i macierzyństwo. Takie jest znaczenie słów Pisma Świętego.: „Mężczyzna poznał żonę swoją Ewę, a ona poczęła i urodziła $(\ldots)^{36}$. Kobieta, stając się matką, ukazuje najpełniej tajemnice męskości mężczyzny: rodzicielskie, ojcowskie znaczenie jego ciała. W przypisie do swoich katechez Jan Paweł II zaznacza, że ojcostwo jest jednym $\mathrm{z}$ aspektów człowieczeństwa, najsilniej uwydatnionych w Piśmie Świętym. Odwołując się do Rdz 5,3: Adamowi „urodził (...) się syn, podobny do niego jako jego obraz", papież podkreśla, że Biblia przyznaje ojcu ziemskiemu uczestnictwo w Boskim dziele przekazywania życia i w łączącej się z tym radości: „i widział Jahwe-Bóg, że było bardzo dobre”37. W perspektywę wzajemnego „poznania” mężczyzny i kobiety włączone jest przekazywanie życia - „rodzenie”. Synonimem tego „poznania” staje się określenie teologiczno-prawnicze: „dopełnienie małżeństwa” (matrimonium consummatum), sugerujące swoistą pełnię, jakieś summum w zjednoczeniu mężczyzny i kobiety. To zaś z kolei odwołuje do ojcostwa i macierzyństwa. W determinacji biologicznej człowieka należy odczytać zawarty w niej sens duchowy: miłość - jedność - poznanie - życie. „Ten sam «człowiek» jako mężczyzna/ niewiasta, poznający siebie wzajemnie w tej szczególnej wspólnocie/komunii osób, w której mężczyzna i kobieta łączą się ze sobą tak ściśle, iż stają się jednym ciałem, konstytuuje człowieczeństwo, to znaczy potwierdza i odnawia istnienie człowieka jako obrazu Boga. Za każdym razem oboje: mężczyzna i kobieta obraz ten przejmują niejako z tajemnicy stworzenia

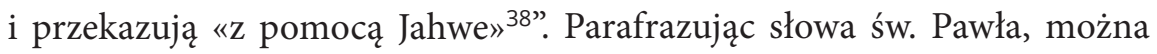
powiedzieć, że to wzajemne „poznanie” w imię komunii miłości jest „silniejsze niż śmierć" (fortis ut mors dilectio) ${ }^{39}$.

\footnotetext{
$36 \operatorname{Rdz} 4,1$.

37 Por. Rdz 1,31; Jan Paweł II, Mężczyzną i niewiastą stworzył ich, dz. cyt., s. 85.

38 Jan Paweł II, Mężczyzna i niewiasta stworzył ich, dz. cyt., s. 88.

39 Pnp 8,6.
} 


\subsection{Sakrament małżeństwa}

Jan Paweł II poświęcił drugą część katechez środowych na temat małżeństwa i rodziny problematyce sakramentu małżeństwa. Podstawą dla nauczania papieskiego jest fragment Listu do Efezjan ${ }^{40}$, który nawiązuje wprost do biblijnego „początku”, zawartego w słowach Księgi Rodzaju ${ }^{41}$ : „opuści człowiek ojca i matkę, a połączy się z żoną swoją, i będą dwoje jednym ciałem". Tym samym tekst Listu do Efezjan staje się pomostem między pierwszą a drugą częścią katechez środowych. Jeśli chodzi o autorstwo tego tekstu, papież przyjmuje „hipotezę kompromisową”: św. Paweł napisał czy też podyktował list sekretarzowi, który następnie uzupełnił go i wykończył. Z tym założeniem ojciec święty używa zamiennie takich określeń, jak: „Autor Listu do Efezjan”, „Apostoł” czy wręcz „św. Paweł”42. Papież kilkakrotnie podejmuje tezę stawianą w związku z tekstem Ef 5,21-33: czy tekst ten mówi wprost o sakramentalności małżeństwa? Papież przywołuje najpierw zasadę: lex orandi wypływa zawsze z lex credendi, a w liturgii tekst ten pojawia się zawsze w związku z sakramentem małżeństwa. Dalej ojciec święty przyjmuje powszechną opinię biblistów i teologów, że Autor Listu do Efezjan nie porusza wprost i w ścisłym znaczeniu tematu sakramentu małżeństwa. Papież podkreśla jednak, że Ef 5,21-33 mówi o podstawach sakramentalności całego życia chrześcijańskiego, a w szczególności o podstawach sakramentalności małżeństwa. Innymi słowy tekst ten mówi o sakramentalności małżeństwa w sposób pośredni, ale równocześnie zasadniczy ${ }^{43}$. Święty Paweł używa analogii terminu „ciało” w odniesieniu do dwóch rzeczywistości: Kościół jako Ciało Chrystusa oraz ciało ludzkie, będące fundamentem jedności małżeńskiej, w swojej specyfice kobiecości i męskości.

Jeśli przyjmujemy, że sakrament jest „znakiem widzialnym rzeczywistości niewidzialnej", duchowej, Bożej, to jako znak widzialny dotyczy ciała ludzkiego, odwołuje do „teologii ciała”.

Autor Listu do Efezjan podaje szczegółowe wskazania dla wspólnoty chrześcijańskiej, a w jej obrębie dla wspólnoty domowej, dla rodziny. Ukazuje, w jaki sposób poszczególni jej członkowie mają realizować powołanie

\footnotetext{
40 Ef 5,21-33.

$41 \quad \operatorname{Rdz} 2,24$.

42 Jan Paweł II, Mężczyzna i niewiasta stworzył ich, dz. cyt., s. 338.

$43 \mathrm{~W}$ związku z tą refleksją ojciec święty określa, jak należy rozumieć pojęcie sakramentu. Por. Mężczyzna i niewiastą stworzył ich, dz. cyt., s. 360-362, p. 1.
} 
Chrystusowe. Są to więc pouczenia o obowiązkach moralnych społeczności rodzinnej ${ }^{44}$. Ściśle wzięty tekst Ef 5,21-33 koncentruje się wyłącznie na małżonkach i małżeństwie.

\section{Wzajemne poddanie w Chrystusie}

Punktem wyjścia w refleksji na temat relacji pomiędzy mężem a żoną jest zalecenie św. Pawła, aby małżonkowie byli sobie „wzajemnie poddani w bojaźni Chrystusowej" ${ }^{2}$. Kryterium odniesienia ma być zawsze Chrystus, Jego Boska nauka. Poddanie, wypływające z ducha Chrystusowego, ma być wzajemne, tzn. zarówno kobiety wobec mężczyzny, jak i mężczyzny wobec kobiety. W tym świetle należy więc odczytać następne słowa Apostoła: „Żony niech będą poddane swym mężom, jak Panu (...)"46. Wobec licznych prób interpretacji tych słów jako konieczności poddania mężczyźnie kobiety Jan Paweł II stwierdza wyraźnie: „Autor [Listu do Efezjan - przyp. B. M.] nie chce przez to powiedzieć, że mąż jest «panem» żony, że właściwy dla małżeństwa układ międzyosobowy jest układem panowania męża nad żoną. Wyraża natomiast inną myśl: żona w swym odniesieniu do Chrystusa, który jest dla obojga małżonków jedynym Panem, może i powinna znajdować pokrycie dla takiego odniesienia do męża, które wynika z samej istoty małżeństwa i rodziny. Odniesienie to nie jest jednakże poddaniem jednostronnym. Małżeństwo wedle nauki Ef 5,21-33 wyklucza układ, który ciążył - i nieraz jeszcze ciąży - nad tą instytucją. Mąż i żona bowiem są sobie «wzajemnie poddani», wzajemnie podporządkowani. Źródłem tego wzajemnego poddania jest chrześcijańska "pietas», a wyrazem - miłość" ${ }^{77}$. Chrześcijańska miłość wyklucza dominację jednej osoby nad drugą. Jeśli żona ma być poddana mężowi, to nie w sensie służącej czy niewolnicy. Równocześnie mąż ma być poddany żonie. Źródłem i wzorem tego poddania, a raczej wzajemnego

44 Jan Paweł II nie waha się użyć na oznaczenie tych obowiązków określenia pochodzącego od Marcina Lutra: Haustafeln - tabele norm domowych. Jan Paweł II, Mężczyzną i niewiasta stworzył ich, dz. cyt., s. 344 .

45 Ef 5,21 .

46 Ef 5,22.

47 Jan Paweł II, Mężczyzną i niewiastą stworzył ich, dz. cyt., s. 345. 
oddania, jest dla małżonków Chrystus. To On nadaje ostateczny sens jedności męża i żony, sprawia, że ich więź staje się communio personarum.

\section{Analogia Chrystus/Kościół - mąż/żona}

Święty Paweł w analizowanym przez Jana Pawła II tekście posługuje się językiem analogii: relacje między małżonkami, mężem i żoną, winny być przez chrześcijan ujmowane na podobieństwo relacji między Chrystusem a Kościołem. Miłość łącząca męża i żonę ma być przede wszystkim obrazem miłości Chrystusa i Kościoła, w której to realizuje się odwieczny Boży plan zbawienia człowieka. Z tej analogii wypływa zasadnicza prawda o małżeństwie: „Małżeństwo wówczas tylko odpowiada powołaniu chrześcijan, jeżeli odzwierciedla się w nim owa miłość, jaką Chrystus-Oblubieniec obdarza Kościół-Oblubienicę, i jaką Kościół (na podobieństwo żony «poddanej», a więc w pełni oddanej) stara się odwzajemniać Chrystusowi. Jest to miłość zbawcza, odkupieńcza - ta miłość, którą człowiek został odwiecznie umiłowany przez Boga w Chrystusie"48.

Analogia mąż/żona - Chrystus/Kościół ma charakter zwrotny, działa w obu kierunkach. Z jednej strony ukazuje istotne związki Chrystusa z Kościołem, z drugiej - pozwala lepiej zrozumieć sens małżeństwa jako więzi między mężczyzną a kobietą, wypływającej z odwiecznej miłości Bożej ku człowiekowi, zakorzenionej w odkupieńczej miłości Chrystusa do Kościoła. Dodatkowy aspekt omawianej analogii stanowi relacja głowa-ciało: „Mąż jest głową żony, jak i Chrystus - głową Kościoła: On - Zbawca Ciała"49.

Jan Paweł II przypomina swoją poprzednią uwagę, że także to zdanie należy interpretować nie $\mathrm{w}$ sensie dominacji mężczyzny nad kobietą, lecz „wzajemnego poddania w bojaźni Chrystusowej”50. Analogia głowa-ciało nasuwa myśl o organicznej jedności między mężem a żoną, na wzór jedności między Chrystusem a Kościołem. Przypominają się tu słowa Księgi Rodzaju ${ }^{51}$. Ta organiczna jedność małżonków w niczym nie niszczy ich

\footnotetext{
48 Jan Paweł II, Mężczyzną i niewiastą stworzył ich, dz. cyt., s. 348.

49 Ef 5,23.

50 Por. Ef 5,21.

$51 \mathrm{Rdz} 2,24$.
} 
odrębności, jak to określa papież, ich „dwupodmiotowości”52. Autor Listu do Efezjan dwukrotnie upomina mężczyzn: „Mężowie, miłujcie żony, bo i Chrystus umiłował Kościół i wydał za niego siebie samego (...). Mężowie powinni miłować swoje żony, tak jak własne ciało"53.

Wymowny jest ten zwrot „kochać swą żonę jak własne ciało”. „Miłość każe oblubieńcowi-małżonkowi troszczyć się o wszelkie dobro oblubienicy-małżonki, każe mu pragnąć jej piękności, zarazem odczuwać tę piękność i troszczyć się o nią. Chodzi tu również o piękność widzialną, piękność ciała" ${ }^{4}$. Zwrot Pawłowy zawiera też ideę dobra, którym chce się obdarzyć ukochaną osobę: „owo dobro, jakie stwarza miłujący przez swoją miłość w tym, kogo miłuje, jest jakby sprawdzianem samej miłości, jest jakby miarą tej miłości”55. Organiczna jedność, która powstaje między małżonkami, ma charakter moralny, a nie ontyczny; jest to jedność, która rodzi się z miłości: „Kto miłuje swoją żonę, siebie samego miłuje”56. Głęboka jedność męża i żony, w imię miłości, wyraża się także poprzez ciało.

Dlaczego Autor Listu do Efezjan wzywa tylko mężczyznę, by kochał swoją żonę? Według interpretacji papieskiej trzeba byłoby słowo „tylko” zastąpić słowem „przede wszystkim”. Następnie należy wziąć pod uwagę strukturę obrazu Pawłowego: „Chociaż małżonkowie mają być «sobie wzajemnie poddani w bojaźni Chrystusowej», to jednak w dalszym ciągu mąż jest przede wszystkim tym, który miłuje - żona zaś tą, która doznaje miłości. Można by nawet zaryzykować opinię, że «poddanie» żony mężowi rozumiane w kontekście całego fragmentu Ef 5,21-33 oznacza nade wszystko «doznawanie miłości» (...). Doznając miłości oblubieńczej małżonka, żona jego staje się «jednym ciałem» z nim: poniekąd «własnym» jego ciałem" 57 . Nic więc dziwnego, że mąż - w imię miłości - ogarnia wszechstronną troską swą żonę: tak jak własne ciało. Otacza kobietę opieką, jako żonę i matkę ich wspólnych dzieci.

\footnotetext{
52 Por. rozważanie na temat dwupodmiotowości. Jan Paweł II, Mężczyzną i niewiastą stworzył ich, dz. cyt., s. 352-356.

53 Ef 5,25.28.

54 Jan Paweł II, Mężczyzną i niewiastą stworzył ich, dz. cyt., s. 356.

55 Jan Paweł II, Mężczyzną i niewiastą stworzył ich, dz. cyt., s. 356.

56 Ef 5,28.

57 Te słowa, przytoczone przez papieża z konstytucji Gaudium et spes, 24, wskazują wyraźnie na analogię małżeństwa w stosunku do Trójcy św. Por. Jan Paweł II, Mężczyzną i niewiastą stworzył ich, dz. cyt., s. 389.
} 
Autor Listu do Efezjan na potwierdzenie swojej nauki przytacza słowa Księgi Rodzaju: „Dlatego opuści człowiek ojca i matkę, a połączy się z żoną swoją, i będą dwoje jednym ciałem" 58 . Jan Paweł II uważa je za zwornik całego komentowanego tekstu, niejako jego streszczenie. Nie jest więc rzeczą przypadku, że do tych słów Apostoł dołącza słynne zdanie: „Tajemnica to wielka, a ja mówię: w odniesieniu do Chrystusa i Kościoła"59. Chodzi tu o tajemnicę najpierw ukrytą w planach Bożych, a następnie objawioną w dziejach człowieka. Zwrot „wielka tajemnica” mówi pośrednio o podstawach sakramentu małżeństwa. „Chrystus, który aktem miłości odkupieńczej umiłował Kościół i wydał za niego samego siebie, tym samym aktem zjednoczył się z Kościołem na sposób oblubieńczy, podobnie jak jednoczą się z sobą mąż i żona w ustanowionym przez Stwórcę małżeństwie"60.

W dalszej części swego listu święty Paweł wzywa małżonków chrześcijańskich do tego, aby przyjmując wiarą Objawienie Boże, kształtowali swe życie w duchu poznanej prawdy. Tekst Listu do Efezjan staje się paranezą, czyli pouczeniem o moralnych aspektach powołania chrześcijan, w tym wypadku powołania małżeńskiego.

Jan Paweł II przeprowadza ciekawe porównanie fragmentu proroka Izajasza $^{61} \mathrm{z}$ analizowanym tekstem Listu do Efezjan ${ }^{62}$. Tematem tego porównania jest analogia miłości oblubieńczej i małżeństwa. Miłość Boga-Jahwe do Izraela-Ludu Wybranego wyraża się jako miłość mężczyzny-oblubieńca do wybranej kobiety, która stanie się jego żoną przez przymierze małżeńskie.

Jednakże istnieje pewna różnica między Izajaszem a Listem do Efezjan. Tajemnica miłości i wybrania ludzi przez Boga jest głównie tajemnicą miłości ojcowskiej i wyprzedza analogię miłości oblubieńczej i małżeństwa. Ta druga pojawia się wtedy, gdy Bóg ukazuje się jako Odkupiciel w swoim Synu Jednorodzonym. W Chrystusie zostaliśmy wszyscy umiłowani przez Ojca. „W Nim mamy odkupienie przez Jego krew - odpuszczenie występków według bogactwa Jego łaski”63. Stąd płynie wniosek: „Perspektywa teologiczna prorockiego tekstu zostaje w Liście do Efezjan zachowana i równocześnie pogłębiona i przetworzona. Wchodzą w nią nowe momenty objawione:

\footnotetext{
$58 \quad \operatorname{Rdz} 2,24$.

59 Ef 5,32.

60 Jan Paweł II, Mężczyzną i niewiastą stworzył ich, dz. cyt., s. 362-363.

61 Iz 54,4-7.10.

62 Jan Paweł II, Mężczyzną i niewiastą stworzył ich, dz. cyt., s. 366-374.

63 Ef $1,7$.
} 
moment trynitarny, chrystologiczny i wreszcie eklezjologiczny" ${ }^{64}$. Analogia małżeństwa odnosi się przede wszystkim do momentu eklezjologicznego.

\section{4. „Sakrament stworzenia i odkupienia”}

Trzy pojęcia, które występują w refleksji Jana Pawła II w odniesieniu do sakramentu małżeństwa - sakrament najpierwotniejszy, sakrament stworzenia, sakrament odkupienia - wyrażają, każdy na swój sposób, treść zawartą w związku mężczyzny i kobiety. Małżeństwo jest dlatego sakramentem najpierwotniejszym, ponieważ stanowi integralną część i centralny punkt Bożego planu stworzenia pierwszych ludzi, określonego jako „sakrament stworzenia”. "Sakrament odkupienia" natomiast to ponowne obdarowanie człowieka - już po grzechu - przez Chrystusa, który „umiłował swój Kościół i wydał za niego samego siebie, aby go uświęcici” ${ }^{65}$. W tym „sakramencie odkupienia" mieści się analogia Chrystus/Kościół - mąż/żona.

$\mathrm{W}$ jednym i drugim wypadku istotą jest miłość nierozerwalna, która łączy oba elementy. Małżeństwo jest „figurą” i sakramentem Nowego Przymierza. „Chrystus w swej rozmowie z faryzeuszami ${ }^{66}$ nie tylko potwierdza istnienie małżeństwa ustanowionego przez Stwórcę «od początku», ale także czyni je częścią integralną tej nowej ekonomii sakramentalnej, nowego porządku zbawczych «znaków», który bierze początek w sakramencie odkupienia $(\ldots)^{\prime \prime 67}$.

\subsection{Nierozerwalność małżeństwa}

$\mathrm{W}$ rozmowie z faryzeuszami Chrystus akcentuje nierozerwalność małżeństwa ${ }^{68}$, odwołując się do „początku”. Zdanie: „Co więc Bóg złączył, niech człowiek nie rozdziela”69, ma charakter imperatywny. Jan Paweł II pod-

\footnotetext{
64 Jan Paweł II, Mężczyzna i niewiastą stworzyt ich, dz. cyt., s. 370.

65 Ef 5,25-26.

66 Mt 19,3-9.

67 Jan Paweł II, Mężczyzną i niewiasta stworzył ich, dz. cyt., s. 383.

68 Mt 19,3-9.

69 Mt 19,6.
} 
kreśla, że to pouczenie Chrystusowe jest uniwersalne, dotyczy wszystkich czasów i miejsc, właśnie dlatego, że sięga do początków ludzkości. Porządek stworzenia zostaje wzmocniony i uświęcony porządkiem odkupienia. Dochodzi do tego analogia trynitarna. Małżeństwo, sakrament najpierwotniejszy, sakrament stworzenia i odkupienia, prowadzi do komunii osób „na podobieństwo jedności Osób Boskich"70.

Chrystus, przypominając nierozerwalny charakter małżeństwa w planach Boga-Stwórcy, wyciąga równocześnie z tego faktu konsekwencje etyczne: „Kto oddala żonę swoją, a bierze inną, popełnia cudzołóstwo względem niej. I jeśli żona opuści swego męża, a wyjdzie za innego, popełnia cudzołóstwo" "71. Ze słów Zbawiciela można więc wyprowadzić wniosek, że sakrament małżeństwa jest dany mężczyźnie i kobiecie jako łaska i znak Przymierza $z$ Bogiem, a zadany jako etos ${ }^{72}$.

Jednym z zadań, obszernie skomentowanych przez Jana Pawła II, jest „przezwyciężanie pożądliwości”. Chrystus wzywa do jego wypełnienia w Kazaniu na górze ${ }^{73}$. „Owocami takiego zwycięstwa są jedność i nierozerwalność małżeństwa, są nimi ponadto pogłębione poczucie godności kobiety w sercu mężczyzny, jak również godności mężczyzny w sercu kobiety"74.

Echo słów Chrystusowych odnajdujemy w siódmym rozdziale Listu do Koryntian. Święty Paweł zaleca małżeństwo „ze względu na niebezpieczeństwo rozpusty”, a małżonkom zaleca wzajemne „oddawanie powinności małżeńskiej" ${ }^{\prime 75}$. Jan Paweł II odsuwa interpretacje wypowiedzi Apostoła $\mathrm{w}$ takim sensie, jakoby małżeństwo stanowiło swoiste remedium concupiscentiae $^{76}$. Chodzi raczej o ład w perspektywie daru i łaski, jaki wprowadza małżeństwo w sferę psychiki mężczyzny i kobiety.

Papież podkreśla wreszcie, że sakrament małżeństwa jest Bożym wezwaniem do „życia wedle Ducha"77. Prawda o odkupieniu, w tym także odkupieniu ciała, wnosi w życie małżonków „nadzieję dnia powszedniego”,

70 Tak więc kontynuując myśl II Soboru Watykańskiego, Jan Paweł II oczyszcza niejako tradycję Kościoła ustawiającą remedium concupiscentiae jako jeden z celów małżeństwa.

71 Mk 10,11-12; Por. Mt 19,9.

72 Jan Paweł II, Mężczyzną i niewiastą stworzył ich, dz. cyt., s. 391-394.

73 Mt 5,27-28.

74 Jan Paweł II, Mężczyzną i niewiastą stworzył ich, dz. cyt., s. 393.

75 Por. 1 Kor 7,2-3.

76 Zajmuje ona obszerną część katechez: Jan Paweł II, Mężczyzną i niewiastą stworzył ich, dz. cyt., s. 419-443.

77 Por. Rz 8,4-5; Ga 5,25. 
„nadzieję doczesności”. Ciało staje się dla nich „tworzywem” trwałej i nierozerwalnej komunii osób. „Życie wedle Ducha” jest więc łaską sakramentalną, która „pozwala mężczyźnie i kobiecie odnajdywać prawdziwą wolność daru związaną z poczuciem oblubieńczego sensu ciała w jego męskości i kobiecości”78. Swój szczególny wyraz znajduje to w rodzicielstwie.

Powyższe rozważania papieskie można byłoby zamknąć wymownym stwierdzeniem: „Małżeństwo jako sakrament stanowi podstawę nadziei dla człowieka: dla mężczyzny i kobiety, dla rodziców i dzieci, dla ludzkich pokoleń"79.

\subsection{Znak sakramentalny}

Narzeczeni, udzielają sobie sakramentu małżeństwa, wypowiadając słowa przysięgi małżeńskiej: „Biorę ciebie za żonę, (...) biorę ciebie za męża (...), i ślubuję ci miłość, wierność i uczciwość małżeńską oraz że cię nie opuszczę aż do śmierci”. Nowożeńcy powołują Boga na świadka wypowiadanych przez siebie słów: „Tak mi dopomóż, Panie Boże Wszechmogący, w Trójcy jedyny i Wszyscy Święci”.

Ważnie zawarte małżeństwo zostaje w pełni ukonstytuowane przez pożycie małżeńskie. Jan Paweł II odwołuje się do klasycznego rozróżnienia teologicznego: matrimonium ratum et consumatum. Mężczyzna i kobieta $\mathrm{z}$ woli Bożej i własnego wyboru stają się wtedy „jednym ciałem”. Słowa przysięgi małżeńskiej tworzą znak sakramentalny, pod warunkiem, że odpowiada im osobowa podmiotowość mężczyzny i kobiety, a równocześnie „świadomość ciała” w jego męskości i kobiecości. W ten znak sakramentu małżeństwa wpisany jest jego czynnik integralny, który papież określa jako „mowę ciała” czy też „profetyzm ciała”: „W ten sposób odwieczna i za każdym razem nowa «mowa ciała» jest nie tylko «tworzywem», ale poniekąd samą konstytutywną treścią komunii osób. Osoby - mężczyzna i kobieta stają się dla siebie wzajemnym darem" ${ }^{80}$.

Wspaniały obraz „mowy ciała” odnajdujemy w księdze Pieśni nad Pieśniami. Dlatego w katechezach środowych Jan Paweł II proponuje także

\footnotetext{
78 Jan Paweł II, Mężczyzną i niewiastą stworzył ich, dz. cyt., s. 395.

79 Jan Paweł II, Mężczyzna i niewiasta stworzył ich, dz. cyt., s. 396.

80 Jan Paweł II, Mężczyzną i niewiastą stworzył ich, dz. cyt., s. 405.
} 
interpretację tej księgi ${ }^{81}$. Papież naświetla niezwykłą dynamikę i głębię miłości ludzkiej, miłości między mężczyzną a kobietą, miłości oblubieńczej, ukazanej w Pieśni nad Pieśniami. Podkreśla jej ścisłą relację z rzeczywistością „najpierwotniejszego sakramentu”; integralny związek z „sakramentem stworzenia” i z „sakramentem odkupienia”. Wartość i siła tej miłości zamknęły się w zdaniu: „bo jak śmierć potężna jest miłość” - fortis ut mors dilectio ${ }^{82}$.

Kolejna refleksja biblijna, tym razem nad Księgą Tobiasza, daje ojcu świętemu okazję, by uzmysłowić słuchaczom, w jaki sposób „mowa ciała” może i powinna stać się językiem liturgiii ${ }^{83}$. Podkreślmy tylko jeden element z tych ciekawych rozważań papieskich nad Księgą Tobiasza. Podobnie jak w księdze Pieśni nad Pieśniami, tak i w Księdze Tobiasza uderza kilkakrotne nazwanie żony, oblubienicy, mianem siostry. Nie chodzi tu o pokrewieństwo. Ukazana jest raczej myśl, że poprzez małżeństwo mężczyzna i kobieta w szczególny sposób stają się bratem i siostrą. „Rys siostrzany (i braterski) zdaje się tkwić głęboko w miłości oblubieńczej (...). Wyrażenie «siostra» mówi o jedności w człowieczeństwie i zarazem kobiecej inności, oryginalności tegoż człowieczeństwa. Jest to inność i oryginalność nie tylko ze względu na płeć, ale także ze względu na sam sposób «bycia sobą» (...). Szczególnym adresatem owego otwarcia staje się mężczyzna jako «brat»"84.

Końcowe słowa refleksji Jana Pawła II na temat małżeństwa jako sakramentu to nie tylko „akademickie” streszczenie dotychczasowych wywodów. Zawiera się w nich najgłębsza istota teologii małżeństwa, oddająca wielkość i świętość związku mężczyzny i kobiety, wskazująca na zadania, jakie Bóg przed nimi postawił: „Taki wydaje się integralny sens znaku sakramentalnego małżeństwa: mężczyzna i kobieta wychodzą w nim poprzez «mowę ciała» na spotkanie wielkiego «mysterium», ażeby światło tego «mysterium»: światło prawdy i piękna wyrażone w języku liturgii, przenieść w «mowę ciała», tłumacząc ją na mowę «praxis» miłości, wierności i uczciwości małżeńskiej: na etos tej nadziei, która zakorzeniona została $\mathrm{w}$ «odkupieniu ciała ${ }^{85}$. Na tej drodze życie małżeńskie poniekąd staje się liturgią" ${ }^{86}$. Te bogate

\footnotetext{
81 Zajmuje ona obszerną część katechez: Jan Paweł II, Mężczyzną i niewiastą stworzył ich, dz. cyt., s. 419-443.

82 Pnp 8,6.

83 Jan Paweł II, Mężczyzną i niewiasta stworzył ich, dz. cyt., s. 443-457.

84 Jan Paweł II, Mężczyzną i niewiastą stworzył ich, dz. cyt., s. 428.

$85 \mathrm{Rz} 8,23$.

86 Jan Paweł II, Mężczyzną i niewiastą stworzył ich, dz. cyt., s. 457.
} 
w treść słowa papieskie stanowią równocześnie jasny program dla duszpasterstwa mężczyzn i kobiet, dla duszpasterstwa rodzin. Z punktu widzenia społeczno-prawnego małżeństwo jest umową o ściśle określonej treści. Sprawia ona, że społeczeństwo uznaje związek tego mężczyzny z tą kobietą; na fundamencie tego związku powstaje rodzina, która jest podstawową komórką społeczeństwa.

\section{Odpowiedzialne rodzicielstwo}

Można postawić pytanie, dlaczego Jan Paweł II poświęca ostatnią część swoich katechez środowych encyklice Pawła VI Humanae vitae, dając jej autentyczną wykładnię. Odpowiedź jest oczywista. Przedstawiając zarys teologii ciała, teologii płciowości ludzkiej, w kontekście teologii małżeństwa i rodziny, Jan Paweł II nie mógł pominąć problemu odpowiedzialnego rodzicielstwa. Chciał równocześnie podkreślić aktualność i doniosłość encykliki Humanae vitae. Papież uzupełnia nauczanie II Soboru Watykańskiego oraz Pawła VI własną refleksją przedstawioną w katechezach środowych oraz w adhortacji Familiaris consortio. Zasady odpowiedzialnego rodzicielstwa zawarte w nauczaniu Kościoła ostatnich czasów, głównie w dokumentach: Gaudium et spes, Humanae vitae, Mężczyzna i niewiasta stworzył ich, Familiaris consortio, dotyczą w równym stopniu obojga małżonków. Tym bardziej trzeba je nieustannie przypominać mężczyznom, którzy wykazują szeroko rozpowszechnioną tendencję do przerzucania ciężaru odpowiedzialności w dziedzinie pożycia małżeńskiego na barki kobiety. Równocześnie nie rezygnują oni z prawa do współżycia jako rzekomego obowiązku wypełniania powinności małżeńskiej ze strony żony, argumentując to niekiedy zasadami chrześcijańskimi. Powołują się nawet na tekst św. Pawła: „Niech mąż oddaje powinność małżeńską żonie, a żona mężowi"87.

Katechezy środowe streszczają i interpretują nauczanie zawarte w encyklice Humanae vitae. Ukazują jej podwójny charakter, równocześnie normatywny i pastoralny. W aspekcie normatywnym chodzi o uściślenie i wyjaśnienie moralnych zasad postępowania w dziedzinie odpowiedzialnego rodzicielstwa; w aspekcie pastoralnym przede wszystkim o ukazanie

871 Kor 7,3 . 
możliwości postępowania według tych zasad, to znaczy „możliwości zachowania prawa Bożego"88.

Papież Jan Paweł II ogranicza się do interpretacji jednego fragmentu encykliki Humanae vitae, ale równocześnie zaznacza, że fragment ten ma znaczenie centralne dla poruszonego przez encyklikę problemu. Oto ów tekst: „Kościół (...) naucza, że konieczną jest rzeczą, aby każdy akt małżeński zachował swoje wewnętrzne przeznaczenie do przekazywania życia ludzkiego. Nauka ta, wielokrotnie przez Nauczycielski Urząd Kościoła podana wiernym, ma swoją podstawę w ustanowionym przez Boga nierozerwalnym związku - którego człowiekowi nie wolno samowolnie zrywać - między dwojakim znaczeniem tkwiącym w stosunku małżeńskim: między oznaczaniem jedności i oznaczaniem rodzicielstwa"89.

Jan Paweł II koncentruje się na podwójnej funkcji znaku w zbliżeniu małżeńskim i na nierozerwalności jej dwojakiego charakteru. Chodzi o odczytanie w prawdzie „mowy ciała”, czyli o interpretację wspomnianego fragmentu Humanae vitae w świetle myśli przewodniej całości katechez środowych.

Odczytywanie „mowy ciała” zakłada poszanowanie normy prawa naturalnego: „Albowiem stosunek małżeński z najgłębszej swojej istoty, łącząc najściślejszą więzią męża i żonę, jednocześnie czyni ich zdolnymi do zrodzenia nowego życia, zgodnie z prawami zawartymi w samej naturze mężczyzny i kobiety" ${ }^{\prime 90}$. Zgodność $\mathrm{z}$ naturą to równocześnie zgodność $\mathrm{z}$ nieuprzedzonym rozumem.

Ciekawa, z punktu widzenia teologicznego, jest refleksja Jana Pawła II na temat relacji pomiędzy słusznością normy a jej „wykonywalnością”. Papież definiuje najpierw pojęcie normy: „Norma moralności jest zasadą, w oparciu o którą kształtuje się wartość moralna czynów ludzkich: czyny zgodne $\mathrm{z}$ normą są moralnie dobre, czyny jej przeciwne, niezgodne z nią - moralnie złe" ${ }^{\prime \prime}$. Chociaż nie zawiera się ona formalnie w Piśmie Świętym, to jednak odnajdujemy ją w tradycji oraz w nauczaniu Urzędu Nauczycielskiego

\footnotetext{
88 Paweł VI, Encyklika Humanae vitae, 20. Omówieniu encykliki Humanae vitae poświęcony jest ostatni rozdział katechez środowych, zatytułowany: Prawo życia dał im Bóg w dziedzictwo, w: Jan Paweł II, Mężczyznq i niewiastą stworzył ich, dz. cyt., s. 459-499.

89 Paweł VI, Encyklika Humanae vitae, 11-12.

90 Paweł VI, Encyklika Humanae vitae, 12.

91 Jan Paweł II, Mężczyzną i niewiastą stworzył ich, dz. cyt., s. 462.
} 
Kościoła. Dlatego należy powiedzieć, że odpowiada całokształtowi nauki objawionej zawartej w źródłach biblijnych ${ }^{92}$.

Jan Paweł II zaznacza wyraźnie, że norma moralna, zawarta w encyklice Humanae vitae, dotyczy wszystkich ludzi, ponieważ wypływa z prawa natury. Humanae vitae stanowi rozwinięcie i dopowiedzenie nauki przedstawionej w Gaudium et spes, zwłaszcza w zakresie „uzgadniania miłości małżeńskiej z poszanowaniem życia ludzkiego": Kościół przypomina jednak, że nie może być rzeczywistej sprzeczności między Boskimi prawami dotyczącymi z jednej strony przekazywania życia, a z drugiej pielęgnowania prawdziwej miłości małżeńskiej"93.

Po naświetleniu zagadnienia normy zawartej w Humanae vitae Jan Paweł II przechodzi do rozważań pastoralnych, do których skłania charakter obu dokumentów: zarówno Gaudium et spes, jak i Humanae vitae. Ta - tak często krytykowana i odrzucana - encyklika przynosi zdaniem Jana Pawła II odpowiedź na różnorodne pytania stawiane przez współczesnych ludzi: przez demografów w związku z gwałtownym przyrostem ludności na kuli ziemskiej, teologów moralistów, a przede wszystkim - samych małżonków. Tych ludzi i ich pytania ma na myśli Paweł VI, gdy stwierdza: „Nauka Kościoła o należytej regulacji poczęć, będąca promulgacją samego prawa Bożego, wyda się niewątpliwie dla wielu trudna; więcej nawet - zupełnie niemożliwa do zachowania. Bo rzeczywiście, jak wszystkie rzeczy szlachetne i pożyteczne, tak i to prawo wymaga mocnych decyzji i wielu wysiłków od poszczególnych ludzi, od rodzin i społeczności ludzkiej. Co więcej, zachować je można tylko z pomocą łaski Bożej, która wspiera i umacnia dobrą wolę ludzi. Kto jednak uważniej się nad tym zastanowi, dostrzeże, że owe wysiłki naprawdę podnoszą godność człowieka i przysparzają dobra całej ludzkości"94.

W świetle nauki Kościoła odpowiedzialne rodzicielstwo zawiera trzy elementy składowe: ${ }^{95}$

- dojrzałość sumienia;

- jego zgodność z prawem Bożym;

\footnotetext{
92 Por. Paweł VI, Encyklika Humanae vitae, 4.

93 Sobór Watykański II, Gaudium et spes, 51.

94 Paweł VI, Encyklika Humanae vitae, 20.

95 Por. Jan Paweł II Mężczyzną i niewiasta stworzył ich, dz. cyt., s. 468.
} 
- uwzględnianie wskazań Magisterium w dziedzinie przekazywania życia ludzkiego.

Paweł VI wymienia kilka aspektów odpowiedzialnego rodzicielstwa: biologiczny, psychologiczny, ekonomiczno-społeczny, i w zależności od nich definiuje pojęcie odpowiedzialnego rodzicielstwa. Jednakże głównym i podstawowym aspektem pozostaje „obiektywny porządek moralny, ustanowiony przez Boga, którego to porządku prawdziwym tłumaczem jest prawe sumienie (...). Małżonkowie winni dostosować swoje postępowanie do planu Boga-Stwórcy"96.

Wychodząc z tej zasady, Humanae vitae ściśle rozróżnia dwa wykluczające się nawzajem sposoby ograniczania liczby potomstwa: niedopuszczalny z punktu widzenia moralnego i moralnie dopuszczalny. Niedopuszczalne są: bezpośrednie przerywanie ciąży, sterylizacja oraz „wszelkie działanie, które - bądź to w przewidywaniu zbliżenia małżeńskiego, bądź podczas jego spełnienia, czy w rozwoju jego naturalnych skutków - miałoby za cel uniemożliwienie poczęcia lub prowadziło do tego" ${ }^{\text {97 }}$. Niedopuszczalne są więc „wszelkie metody antykoncepcyjne, nawet te, które nie naruszają cielesnej struktury stosunku małżeńskiego ${ }^{98}$. Moralnie dopuszczalne natomiast jest korzystanie z okresów naturalnej niepłodności kobiety.

Małżonkowie winni sobie uświadomić, że istnieje istotna różnica, natury etycznej, między korzystaniem z okresów niepłodności a antykoncepcją. „W pierwszym wypadku małżonkowie w sposób prawidłowy korzystają z pewnej właściwości danej im przez naturę. W drugim zaś stawiają oni przeszkodę naturalnemu przebiegowi procesów związanych z przekazywaniem życia" 99 .

Po tym przypomnieniu nauki zawartej w Humanae vitae Jan Paweł II przechodzi do jej analizy w świetle teologii ciała, która jest zwornikiem całości katechez środowych na temat małżeństwa. Główne elementy tej analizy to: „prawda mowy ciała a zło antykoncepcji”, „prymat cnoty w etycznej regulacji poczęć”, „omówienie czynników składowych etycznej regulacji poczęć: osoba - natura - metoda"100.

\footnotetext{
96 Paweł VI, Encyklika Humanae vitae, 10.

97 Paweł VI, Encyklika Humanae vitae, 14.

98 Jan Paweł II cytuje te słowa ze swojego wprowadzenia do encykliki Humanae vitae, „Notificationes e Curia Metropolitana Cracoviensi” (1969) nr 1-4, s. 85.

99 Paweł VI, Encyklika Humanae vitae, 16.

100 Jan Paweł II, Mężczyzną i niewiasta stworzył ich, dz. cyt., s. 471-480.
} 
Paweł VI w encyklice Humanae vitae odpowiada na pytanie, na czym polega autentyczne dobro człowieka jako osoby: mężczyzny i kobiety, oraz w jaki sposób zachować godność ludzką w dziedzinie przekazywania życia. Jan Paweł II uzupełnia te refleksje, mówiąc o zachowaniu równowagi między tendencją do panowania nad światem, a koniecznością samopanowania, panowania nad sobą ze strony mężczyzny i kobiety. W dziedzinie przekazywania życia metoda samopanowania jest naturalna, bo respektuje integralność osoby. Metody „sztuczne” natomiast pozbawiają człowieka podmiotowości działania, czynią go przedmiotem manipulacji. „Mowa ciała” to nie tylko aktywność seksualna. Jest to cały, niezwykły dialog między mężczyzną a kobietą, zapoczątkowany w dniu stworzenia.

Dar ze siebie, w pełni świadomy i wolny, nadaje sens jedności małżeńskiej. Zło antykoncepcji polega na zakłóceniu wewnętrznego ładu zjednoczenia małżeńskiego. Akt małżeński, pozbawiony swej wewnętrznej prawdy, tzn. ukierunkowania na nowe życie, przestaje być aktem miłości.

Encyklika Humanae vitae, wykazując i odrzucając zło moralne antykoncepcji, wskazuje jako drogę wyjścia etyczną regulację poczęć. Paweł VI rozwija pojęcie okresowej wstrzemięźliwości. Chociaż termin „okresowa” wskazuje na rytm biologiczny, to jednak stojące obok słowo „wstrzemięźliwość” zakłada wyraźnie określoną postawę moralną: nie „technika stosunków małżeńskich”, ale etyka zjednoczenia małżeńskiego. Jan Paweł II ujmuje tę prawdę z właściwą sobie wnikliwością: „Chodzi zatem wyraźnie - w wypadku etycznej regulacji poczęć, która realizuje się na drodze okresowej wstrzemięźliwości - o praktykowanie czystości małżeńskiej, czyli określonej postawy etycznej. Mówiąc językiem biblijnym: chodzi o «życie wedle Ducha»"101.

Papież przypomina, że ta etyczna regulacja poczęć nosi również nazwę „naturalnej regulacji poczęć”, co wyraża jej zgodność z prawem natury. Wobec nieporozumień, niejasności w formułowaniu definicji „prawa natury” Jan Paweł II określa je jako „odczytywany rozumem «porządek natury» $\mathrm{w}$ dziedzinie prokreacji: porządek ten jest wyrazem urzeczywistniającego się w naturze planu Stwórcy"102.

Snując rozważania na temat trzech elementów zawartych w etycznej regulacji poczęć: osoba, natura, metoda, papież podkreśla, że zadaniem

101 Por. Ga 5,25; Jan Paweł II, Mężczyzną i niewiastą stworzył ich, dz. cyt., s. 477.

102 Jan Paweł II, Mężczyzną i niewiastą stworzył ich, dz. cyt., s. 477. 
człowieka, jako istoty rozumnej i wolnej, jest odczytywanie tej prawidłowości biologicznej, która wkomponowana jest w naturę mężczyzny i kobiety. Równocześnie przestrzega: „Wykorzystywanie «cyklu bezpłodności» w ramach współżycia małżeńskiego może stawać się źródłem nadużyć, jeżeli małżonkowie starają się na tej drodze wykluczyć swoje rodzicielstwo lub zredukować je poniżej słusznego wymiaru dzietności swojej rodziny"103. Papież zaraz tłumaczy, co rozumie przez „słuszny wymiar dzietności”. Ustalając go, małżonkowie winni wziąć pod uwagę nie tylko dobro własnej rodziny, w tym swoje zdrowie i możliwości, lecz także dobro społeczeństwa, w którym żyją, a nawet dobro całej ludzkości. „Nikt bowiem nie jest samotną wyspą"104. Akceptacja powołania Bożego, zgodność ze swoim sumieniem, postawa otwarta wobec drugich - oznaczają również gotowość przyjęcia liczniejszego potomstwa ze strony małżonków chrześcijańskich.

\section{Zarys duchowości małżeńskiej}

\subsection{Moc płynąca z sakramentu małżeństwa}

Tytułem tym określa Jan Paweł II ostatni fragment swoich katechez środowych na temat małżeństwa. Tu także nawiązuje do encykliki Pawła VI Humanae vitae. Z niej bowiem, zdaniem Jana Pawła II, można wyprowadzić elementy duchowości życia małżeńskiego i rodzinnego.

Sakrament małżeństwa udziela małżonkom szczególnej „mocy”, dzięki której dają oni świadectwo chrześcijańskiego życia we współczesnym świecie, niezależnie od realnych trudności, jakie napotykają na co dzień. Tą mocą zasadniczą i podstawową jest miłość zaszczepiona w sercu przez Ducha Świętego. Dzięki niej małżonkowie uczestniczą w miłości Bożej, zawartej w tajemnicy stworzenia i odkupienia ${ }^{105}$. Małżonkowie mają ją czerpać z modlitwy, z Eucharystii oraz z sakramentu pokuty ${ }^{106}$.

103 Jan Paweł II, Mężczyzną i niewiastą stworzył ich, dz. cyt., s. 478. W takim wypadku naturalna regulacja poczęć staje się de facto antykoncepcją ze względu na intencję działających osób.

104 Tytuł głośnego dzieła konwertyty angielskiego, trapisty Thomasa Mertona.

105 Jan Paweł II, Mężczyzną i niewiastą stworzył ich, dz. cyt., s. 483.

106 Por. Paweł VI, Encyklika Humanae vitae, 25. 
Autentyczna miłość między mężczyzną i kobietą stoi na straży związku małżeńskiego. Zabezpiecza zarówno wartość zjednoczenia małżonków, jak i wartość rodzicielstwa, czyniąc je rodzicielstwem odpowiedzialnym. W ten sposób miłość łączy prawidłowo „podwójną funkcję znaku” zawartą w „mowie ciała”. „Miłość ta, jak wynika z tekstu encykliki ${ }^{107}$, pozostaje organicznie sprzymierzona z czystością, która przejawia się jako opanowanie, czyli wstrzemięźliwość, m.in. także jako tzw. „wstrzemięźliwość okresowa”108. We wstrzemięźliwości i opanowaniu chodzi o zdolność stawiania oporu pożądliwości ciała i jej skutkom w całej psychosomatycznej podmiotowości człowieka. Gdy ta zdolność przybiera charakter stałej sprawności, można ją nazwać cnotą ${ }^{109}$. Bardzo ważnym stwierdzeniem papieża jest myśl, że opanowanie i wstrzemięźliwość nie zubożają różnorodnych „znaków miłości” między mężem a żoną, lecz ją uduchowiają, intensyfikują i wzbogacają ${ }^{110}$. Akt małżeński jest szczególnym znakiem miłości, gdyż wyraża równocześnie zjednoczenie osobowe i potencjalne rodzicielstwo mężczyzny i kobiety.

W dalszym ciągu swej refleksji Jan Paweł II wprowadza ciekawe rozróżnienie pomiędzy „podnieceniem” a „wzruszeniem”, dochodzącymi do głosu w kontakcie męskości i kobiecości w małżeństwie ${ }^{111}$. Podniecenie ma przede wszystkim charakter cielesny, seksualny, wzruszenie natomiast odnosi się do „całego” drugiego człowieka, jest fascynacją jego osobą. Podniecenie zmierza zasadniczo do aktu małżeńskiego; wzruszenie prowadzi do innych „znaków miłości”, w których wyraża się znaczenie oblubieńcze ciała, a nie jego znaczenie rodzicielskie. Opierając się na tym rozróżnieniu, papież formułuje ważną zasadę: „Wstrzemięźliwość, jako umiejętność sterowania «podnieceniem» $\mathrm{i}$ «wzruszeniem» w sferze wzajemnego oddziaływania kobiecości i męskości, powinna spełnić istotne i kluczowe zadanie dla utrzymania równowagi pomiędzy takim zjednoczeniem, w którym małżonkowie chcą wyrazić sobie wzajemnie tylko swoją bliskość i jedność, a takim, w którym przyjmują (bodaj pośrednio) odpowiedzialność rodzicielską"112.

\footnotetext{
107 Por. Paweł VI, Encyklika Humanae vitae, 20.

108 Jan Paweł II, Mężczyzną i niewiastą stworzył ich, dz. cyt., s. 485. Papież dokonuje szczegółowej analizy tej cnoty określonej mianem temperantia w odniesieniu do życia mał-

109 Jan Paweł II, Mężczyzną i niewiastą stworzył ich, dz. cyt., s. 486.

110 Jan Paweł II, Mężczyzną i niewiastą stworzył ich, dz. cyt., s. 487.

111 Jan Paweł II, Mężczyzną i niewiasta stworzył ich, dz. cyt., s. 489-494.

112 Jan Paweł II, Mężczyzną i niewiastą stworzył ich, dz. cyt., s. 492.
} żeńskiego. 


\subsection{Dar czci}

Ostatnim punktem poruszonym przez Jana Pawła II w rozdziale poświęconym duchowości małżeńskiej jest refleksja na temat daru czci (donum pietatis). Pochodzi on od Ducha Świętego i „przyczynia się do tego, że akt małżeński nie zostaje pomniejszony i spłycony w całokształcie małżeńskiego obcowania, że nie doznaje «spowszednienia», że wyraża się w nim stosowna pełnia treści osobowych i etycznych. A także treści religijnych: wzgląd na majestat Stwórcy, wzgląd na oblubieńczą miłość Odkupiciela”113.

\section{Zakończenie}

Niniejsza refleksja została skoncentrowana na nauczaniu papieża Jana Pawła II, zawartym w tzw. katechezach środowych. Nauczanie to, ujmując problematykę małżeństwa, dało wspaniałą syntezę teologii ciała, teologii płciowości ludzkiej. Analizując dokładnie treść tych katechez, musimy stwierdzić, że jest w nich równocześnie przedstawiona głęboka teologia mężczyzny. Dlatego patrząc na mężczyznę z chrześcijańskiego punktu widzenia, zwłaszcza ujmując jego rolę w małżeństwie, nie wolno pominąć katechez środowych Jana Pawła II. Zawarte w nich elementy teologii mężczyzny stanowią bowiem cenne źródło dla zrozumienia i realizacji istotnego powołania mężczyzny, w pełni aktualnego w świecie współczesnym.

\section{Bibliografia}

Bibliografia małżeństwa i rodziny 1945-1989, red. E. Ozorowski, Warszawa 2005.

Frossard A, Nayez pas peur, Paris 1982.

Grześkowiak J., Misterium małżeństwa. Sakrament małżeństwa jako symbol przymierza Boga z ludźmi, Poznań 1993.

113 Jan Paweł II, Mężczyzną i niewiastą stworzył ich, dz. cyt., s. 498. 
Jan Paweł II, Adhortacja apostolska o zadaniach rodziny chrześcijańskiej w świecie współczesnym Familiaris consortio (22.11.1982).

Jan Paweł II, List do rodzin Gratissimam Sane (2.02.1994).

Jan Paweł II. Mężczyzną i niewiastą. Chrystus odwołuje się do „serca”. O Jana Pawła II teologii ciała, red. T. Styczeń, t. 2, Lublin 1987.

Jan Paweł II. Mężczyzna i niewiasta stworzył ich. Chrystus odwołuje się do „początku”. O Jana Pawła II teologii ciała, red. T. Styczeń, t. 1, Lublin 1981.

Jan Paweł II, „Mężczyzną i niewiastą stworzył ich”. Odkupienie ciała a sakramentalność małżenstwa, Watykan 1986.

Kongregacja ds. Nauki Wiary, Deklaracja o niektórych zagadnieniach etyki seksualnej Persona humana (29.12.1975).

Kongregacja ds. Wychowania Katolickiego, Wytyczne wychowawcze w odniesieniu do ludzkiej miłości. Zasadnicze cechy wychowania seksualnego (1.11.1983).

Kosmala K., Krzysteczko H., Odpowiedzialne rodzicielstwo, Katowice 1996.

Lacroix X., Małżenstwo, tłum. K. Kubaszczyk, Poznań 2001.

Majdański K., Wspólnota życia i miłości. Zarys teologii małżeństwa i rodziny, wyd. 2, Poznań 1983.

Małżeństwo i rodzina $w$ świetle nauki Kościoła $i$ współczesnej teologii, red. A. L. Szafrański, Lublin1985.

Meissner K., Suszka B., „A tak już nie sq dwoje, lecz jedno ciało” (Mt 19,6), Poznań 1988.

Mierzwiński B., Małżeństwo, w: Leksykon teologii pastoralnej, red. R. Kamiński, W. Przygoda, M. Fiałkowski, Lublin 2006, s. 448-454.

Mierzwiński B., Mężczyzna, istota nieznana, Warszawa 1999.

Mierzwiński B., Mężczyzna - mąż - ojciec, Otwock 1996.

Miłość, małżeństwo, rodzina, red. F. Adamski, wyd. 3, Kraków 1985.

Moir A., Jessel D., Płeć mózgu. O prawdziwej różnicy między kobieta a mężczyzną, Warszawa 1993.

Papieska Rada ds. Rodziny, Ludzka płciowość: Prawda i znaczenie. Wskazania dla wychowania $w$ rodzinie (8.12.1995).

Paweł VI, Encyklika o zasadach moralnych w dziedzinie przekazywania życia ludzkiego Humanae vitae (25.07.1968). 
Pius XI, Encyklika o małżeństwie chrześcijańskim na tle obecnych stosunków, potrzeb, błędów i wykroczeń w rodzinie i społeczeństwie Casti connubi (31.12.1930).

Rodzina - bezcenny dar i zadanie, red. J. Stala, E. Osewska, Radom 2006.

Romaniuk K., Małżeństwo i rodzina w Biblii, Katowice 1981.

Rychlicki Cz., Sakramentalny charakter przymierza małżeńskiego. Studium teologicznodogmatyczne, Płock 1997.

Ryś M., Psychologia małżeństwa. Zarys problematyki, Warszawa 1993.

Salij J., Małżeństwo, rozwód, związki niesakramentalne, Poznań 2000.

Sikorski T., Rodzina jako źródło ksztattowania człowieka. Od myśli Karola Wojtyły do nauczania Jana Pawła II, „Chrześcijanin w Świecie” (1980) r. $12 \mathrm{nr} 94$, s. 18-28.

Skrzydlewski W., Chrześcijańska wizja miłości, małżeństwa i rodziny, Kraków 1982.

Słownik małżeństwa i rodziny, red. E. Ozorowski, Warszawa 1999.

Sobór Watykański II, Konstytucja duszpasterska o Kościele w świecie współczesnym Gaudium et spes (7.12.1965).

Stworzeni do miłości. Jana Pawła II rozmowy z młodymi, Łomianki 1991.

Teologia małżeństwa i rodziny, red. K. Majdański, t. 1, Warszawa 1980; t. 2, Warszawa 1990.

Toffi T., Duchowość małżeńska, Kraków 2001.

Troska J., Moralność życia małżeńskiego i rodzinnego, Poznań 1994.

Wojtyła K., Miłość i odpowiedzialność. Studium etyczne, wyd. 2, Kraków 1962.

Wojtyła K., Wprowadzenie do encykliki «Humanae vitae», „Notificationes e Curia Metropolitana Cracoviensi” (1969) nr 1-4. 
